\title{
Analysis of Adoption and Intensity Adoption of Soil and Water Conservation Practices: The Case of Goromti Watershed West Shewa Zone, Oromia National Regional State, Ethiopia
}

Hawi Hailu Gessese ( $\square$ hawiha.78@gmail.com )

Ambo University

Aman Rikitu Dassa

Ambo University https://orcid.org/0000-0003-3716-6314

\section{Research Article}

Keywords: Adoption, Intensity of adoption, Physical SWC practices, Double hurdle, Oromia, Ethiopia

Posted Date: January 12th, 2022

DOI: https://doi.org/10.21203/rs.3.rs-1160233/v1

License: (c) (1) This work is licensed under a Creative Commons Attribution 4.0 International License. Read Full License 


\section{Abstract}

In Ethiopia, soil erosion is a severe problem and a major cause of the decline of agricultural productivity. Interventions were taken by introducing SWC practices. However, the adoption rates of these practices remain below the expected levels in Ethiopia and particularly in the study area. Therefore, this study aims to identify factors affecting adoption and intensity adoption of physical SWC practices in the study areas. A three-stage sampling technique was employed to select 150 sample HHs. Both quantitative and qualitative data were collected from primary and secondary sources. Descriptive statistics and a Double hurdle model were used to analyze data. The first stage of the Double hurdle model results showed that sex of HHs, education level, frequency of extension contact, perception on soil erosion problems, family size, and training affect the probability of adoption of physical SWC practices positively and significantly while age affects it negatively and significantly. Age, plot size, steep slope, training, and frequency of extension contact affect the intensity adoption of physical SWC practices positively and significantly. The finding depicts that the identified demographic, physical, socio-economic, and institutional factors influence the adoption and intensity adoption of physical SWC practices so, the Agricultural and Natural resource Office and other concerned bodies should consider these influential factors to enhance HHs' adoption of introduced physical SWC practices and to promote agricultural productivity and environmental quality.

\section{Introduction}

Agriculture is the prominent sector that contributes extremely to economic development in Africa (Mohammed and Teshome, 2015; Agere et al., 2020). Over partial of the African population is employed in the sector (AGRA, 2018; MoARD, 2010; Asnake et al., 2018). The sector accounts for about $42 \%$ of the country's Gross Domestic Product (GDP), $90 \%$ of export revenues, and $85 \%$ of employment (Tsega et al., 2018; CSA, 2018). Despite its significant contribution to livelihoods, the sector faces a persistent challenge due to the depletion of natural resources and soil erosion (Sarah et al., 2018; Agere et al., 2020). As an agrarian nation, Ethiopia's growing economy is facing similar challenges due to lingering soil erosion and land degradation (Asnake et al., 2018; Fontes, 2020).

This has significantly resulted in devastating agricultural productivity (Teklu et al., 2015; Mulat et al., 2020) and increase food insecurity and poverty (Akalu et al., 2016). Land degradation is one of the socioeconomic and environmental challenges in Ethiopia, which is caused by the expansion of agriculture due to ever-growing population, removal of crop residues at harvest, open free grazing of livestock, intensive tillage without SWC practices, and inappropriate land use (Gebeyehu et al., 2013; Tamrat et al., 2018). This is displayed in the form of gully formation, soil fertility depletion and crop yield reduction, and major economic losses (Mulatie et al., 2015; Mulat et al., 2020). In order to control the effects of land degradation, the Government of Ethiopia (GoE) has taken various SWC practices since the mid-1970s on individual and communal lands through the productive safety net and Food for Work Programs (FFW), with a purpose of not just to reducing soil loss but also improving crop yields and livelihood of the rural farmers (Zenebe et al., 2014; Asnake et al., 2018). 
In particular, the central government started massive SWC campaigns in the 1980s, targeting the low potential (drought-prone and highly degraded) parts of the highlands. On the other hand, the government discouraged farmers from implementing SWC practices in the high potential area while encouraging the adoption of alternative improved technologies, such as the use of fertilizers and improved seeds, to enhance productivity per unit of cultivated area (Asnake et al., 2018).

As such, SWC has been considered as an important part of the agricultural extension package in the country since 1991 when the Ethiopian People Republic Democratic Front (EPRDF) came to power. It should however be noted that the introduction of these measures and technologies has largely used the top-down approach with little participation of the target farmers. Consequently, these efforts have generally failed mainly due to a lack of support and awareness among farmers (Nigussie et al., 2015; Asnake et al., 2018).

Participatory watershed management was recognized at the national level since the early 2000 s under the framework of national development strategy. This framework triggered the launching of different sustainable land management programs throughout the country. Along with the national strategy, integrated SWC is implementing different physical and biological SWC practices (such as bench terraces, soil bund, bund stabilizing biological practices, farm forestry, and so on) in the main intervention areas. Similarly, the government of Ethiopia is running a massive SWC campaign for two months every year in the selected areas since 2011 (Asnake et al., 2018).

The campaign aims at encouraging rural farming households to construct SWC structures and change their attitudes towards land degradation and SWC (Gebreselassie et al., 2015; Zenebe et al., 2018). Nevertheless all these efforts by the central government, regional government, donors, and development partners, land degradation remains a serious problem and the adoption of SWC practices is generally low. The low rate of adoption of improved SWC practices is not only usual to Ethiopia; it is a common phenomenon in Sub-Saharan Africa as a whole (Kebede et al., 2018; Million et al., 2019).

As a result, land degradation has continued to be a critical threat to Ethiopian agriculture and to attaining the country's food security targets (Daniel et al., 2015; Birhan et al., 2017). The situation in the Goromti watershed, the study area, is not different from the rest of the country. This watershed faces food production problems, soil erosion, deforestation, and land degradation mainly due to natural and manmade causes. Since 2012, to cope with these problems and with the engagement of stakeholders and active participation of the dwelling community, different SWC practices such as soil bunds, waterway, cutoff drain, fanya juu, terraces, area closure, and afforestation have been practiced. However, the quality, standard, specification, adoption rate of the activities matter.

Agriculture in Ethiopia is not only an economic activity but also a way of life for which agricultural land is an essential resource upon which the welfare of the society is built. Directly or indirectly, the vast majority depends on this sector. This leads to increased vulnerability of the economy and problems related to land degradation (Bunyad et al., 2017). Land degradation, in the form of soil erosion and nutrient depletion is a main threatening factor for aggravating food insecurity and make worse sustainability of agricultural 
production in Ethiopia (Sarah et al., 2018; Agere et al., 2020). Poor watershed management, population growth, and inappropriate farming practices have contributed to a lion share of the losses caused. Besides, poverty with a rapid increase in human population combines with land degradation poses a serious threat to the national economy and household food security. Furthermore, soil erosion impedes agricultural productivity through declining soil quality (loss of organic matter and mineral contents) through excessive surface runoff (Nigatu et al., 2017).

However, in Ethiopia for the past decades, an attempt was made to undertake mitigation measures on soil erosion problems using different approaches for the sustainability of crop production (Fisseha and Tewodros, 2014). As well, the watershed management approach has been applied in the country to reduce environmental degradation and to enhance agricultural productivity which supports sustainable livelihoods security of the households. Recognizing land degradation as a major environmental and socioeconomic problem, the government has made several interventions. As a result, in the Goromti watershed, some parts have been converted with different SWC practices. Nevertheless, the adoption and attainment have fallen far below expectations. The area still loses a tremendous amount of fertile topsoil, and the threat of land degradation is still expanding.

According to Berhanu and Scott (2003), the most important reason for the limited use of SWC practices was HHs' low adoption behavior. Short-term benefits expectations of local communities, technical problems, and insufficient institutional and organizational supports have been blamed for the limited success. Moreover, a result of the reviewed literature indicated demographic, physical, socio-economic, and institutional factors were the underlying causes that affect farmers' knowledge and adoption decisions concerning SWC practices (Mohammed and Teshome, 2015; Million et al., 2019; Muluken et al., 2020).

Addisu et al. (2015) identified the determinants of adoption of SWC practices, farmer's perception of cause and consequence of soil erosion, characterized types of SWC techniques adopted in the watershed and most importantly it explored the relationship between socio-economic and physical characteristics of households and adopted SWC practices in the Goromti watershed.

In addition to this, many studies were conducted on the determinants of the adoption of SWC practices in different areas in Ethiopia. But, very few studies accounted for the determinants of intensity adoption of SWC practices. As well, in the study area, there was no empirical study conducted on factors affecting the intensity adoption of SWC practices. Therefore, this study was trying to narrow the research gap in the study area by analyzing factors affecting the adoption and intensity adoption of physical SWC practices in the Goromti watershed of Ambo woreda, Oromia regional state.

\section{Methodology}

\subsection{Description of the Study Area}


The study was conducted in Goromti Watershed in Oromia Regional State, Ambo Woreda. It is $15 \mathrm{~km}$ far from Woreda capital Ambo town, and $130 \mathrm{~km}$ away from Addis Ababa. Geographically, it is located between $8^{\circ} 49^{\prime} 26^{\prime \prime}$ to $8^{\circ} 55^{\prime} 22^{\prime \prime} \mathrm{N}$ lat. and $37^{\circ} 51^{\prime} 57^{\prime \prime}$ to $37^{\circ} 54^{\prime} 08^{\prime \prime} \mathrm{E}$ long. The watershed is surrounded Dese Aklilo kebele in the West, Gatira in the East, and Gosu Kora kebele in the north, Kiba kebele in the North West, and in the South by Southwest Shewa Zone. The watershed is accessed by the gravel road that connects Ambo town with districts and towns of the South West Shewa Zone. The total area of the watershed is about 1664 ha and is composed of mainly Goromti, Boji Bilo, Ya'i Chebo kebeles.

The watershed is characterized by undulating, rugged, and hilly topography. It has an altitude ranging from 2447 to 3185 mean above sea level (M.a.s.I). The topography of the watershed includes $62 \%$ of the total area is moderately steep to steep (more than $15 \%$ slope), $38 \%$ is between gentle and moderate slope (less than $15 \%$ slope). Concerning the land use system of the watershed is about $65 \%$ is farmland, $3 \%$ is forest and Bushland, $3 \%$ grassing land, $17 \%$ is homestead area, and the remaining $12 \%$ is degraded, gully, and covered by other resources. Geologically, the watershed is covered by Alcalitrachyte sand subordinate basalt and three major soil types dominate the watershed.

According to FAO classification (2006), these soils could be approximated with local names as Haplic Luvisols (biyyo boralee), Haplic Alisols (biyyo diimaa), and Calcic Vertisols (biyyo gurracha). In spite of its proximity to the equator, the watershed enjoys a mild temperature condition and is characterized by a 'Dega' (temperate) agro-climatic zone. The climatic type largely consists of Afro-Alpine temperate and warm temperate climates. The lowest and highest annual average temperatures are 13 and $27^{\circ} \mathrm{C}$, respectively. The rainfall of the area is bimodal, with unpredictable short rains from March to April and the main season ranging from June to September.

The watershed has an annual rainfall ranging from 1500 to $1700 \mathrm{~mm}$. Indigenous trees mainly Juniperus (Gaattira) Olea abyssinica (Ejersa), Hagenia forests (Heexoo), acacia (laaftoo), podocarpus (Birbirsa) Arundinaria alpine (Shimala), and Erythrina Abyssinia (Korchi), and exotic tree species including Eucalyptus globulus (bargamo adii) and Eucalyptus camaldulesis (Bargamo dimaa) are widely found in the study area. Farming system in the area is typically a mixed crop-livestock system of the high lands of the country, where livestock provide the drought power needed for farming operation and a good part of crop residue are fed to livestock (Addisu et al., 2015).

The major crops grown include barley (Hordeum Vulgare), wheat (Triticum Vulgare), oat (Avena sativum), Niger seed (Guizotia abyssinica), field pea (Pisum Vativum), faba bean (Vicia faba), and root crop like potato (Selenium tuberosum). Enset (Ensete Ventricosum) is the most popular perennial crop grown in all homesteads and serves as a staple food and income source for local people. Livestock keeping is a traditional practice in the area since long before other farming systems experienced it. Soil bund, fanya juu, waterways, cut-off drain, and grass strips are the major SWC practices implemented in the area (AWANRO, 2020).

\subsection{Methods of sampling techniques and sample size}


In this study, a two-stage sampling technique was employed to select sample respondents. In the first stage, three micro watersheds were selected from seven micro watersheds using random sampling technique. Then, the HHs in the area was stratified into adapters and non-adopters of physical SWC practices. To this effect, a list of HHs was obtained from the Ambo district agricultural and natural resource office (ADANRO, 2020). At the second stage, 150 samples HHs were selected using Cochran's (1977) simple random sampling procedure. Then the sample size thus obtained was assigned to each micro watersheds based on the probability proportional size of the HHs.

$$
\mathrm{n}=\frac{\mathrm{z}^{2} \mathrm{qp}}{\mathrm{e}^{2}}
$$

$$
=\frac{(1.96)^{2}(0.53)(0.47)}{(0.08)^{2}}=150
$$

Where:

$n=$ is the sample size for the study

$z^{2}=$ is the selected critical value of desired confidence level (1.96)

$p=$ is the estimated proportion of an attribute that is present in the population which is 0.47 in this study

$q=1-p$ that is 0.53

$e^{2}=$ is the desired level of precision which is 0.08

Table 1

Sample household heads in selected Micro watersheds

\begin{tabular}{|llllll|}
\hline Watershed & $\begin{array}{l}\text { Micro } \\
\text { watersheds }\end{array}$ & $\begin{array}{l}\text { Total household } \\
\text { heads }\end{array}$ & \multicolumn{2}{l}{$\begin{array}{l}\text { Sampled household } \\
\text { heads }\end{array}$} & $\begin{array}{l}\text { Total } \\
\text { sample }\end{array}$ \\
\cline { 3 - 5 } & Bero & 134 & Adopters & $\begin{array}{l}\text { Non- } \\
\text { adopters }\end{array}$ & \\
\hline Goromti & Yamure & 153 & 21 & 23 & 44 \\
\hline & Kabi & 178 & 23 & 25 & 48 \\
\hline Total & & 465 & 27 & 31 & 58 \\
\hline Source: AWANRO, 2020 & & 71 & 79 & 150 \\
\hline
\end{tabular}

\subsection{Data types, sources and collection tools}


In this study, both primary and secondary data sources were used. To secure primary data, a semistructured questionnaire was used and administrated by personnel interview. The questionnaire was designed to capture household socio-economic, demographic, physical and institutional factors. Typically, the questionnaire format comprises both qualitative and quantitative questions. Before data collection, the questionnaire was tested. This led to a further revision of the questionnaire to make sure that important factors addressed well. On top of this, enumerators had trained on the study's objectives, the questionnaire's content, and approach to handling the respondents. Furthermore, a focus group discussion secondary were used to supplement information collected from respondents.

\subsection{Method of data analysis}

\subsubsection{Descriptive and inferential statistics analysis}

In this study, descriptive statistics were used to describe the socio-economic, demographic, physical and institutional relevant characteristics of sample HHs using mean, standard deviation, percentages, minimum, and maximum. Correspondingly, inferential statistics were also employed to compare the proportion and mean of the difference between physical SWC practices adopter and non-adopter HHs in terms of the dummy and continuous variables using the Chi-square $\left(X^{2}\right)$ test and t-test. The result was presented using the table, pie chart and graph.

\subsubsection{Econometric Analysis}

The Double hurdle model is used to identify factors affecting the adoption and intensity of adoption of physical SWC practices. Most recent literature (Hassen, 2013; Eyerusalem, 2017; Alemayehu et al., 2019; Amsalu and Alebachew, 2020) implemented a double hurdle model to identify factors that affect the adoption and intensity of the adoption of agricultural technologies. The double hurdle model allows the decision to adopt and intensity of adoption of physical SWC to be treated separately. Therefore, a separate process can be used to model the probability of adoption and level of adoption (Carroll et al., 2005).

Generally, the Tobit model has the problem of assumption. It assumes the same set of variables determine both the probability of adoption and the intensity of adoption. Due to this assumption, the same variables, in the same way, introduce consistency bias in the model. According to Andrew (1989) one of the important differences between these two models concerns the sources of zeros. Plus the Heckman model is limited because it assumes that, the non-adopters never adopt under any circumstances. In contrast, in the double hurdle model, non-adopters are considered as a corner solution in a utility maximizing model. Hence, a double hurdle model was employed in this study to minimize those problems.

According to Cragg's model, a HH faces two hurdles while deciding on SWC practices. The first is to decide whether or not to adopt physical SWC practices. The second hurdle is related to the intensity of adoption, or the proportion of area covered by physical SWC practices. The most important underlying assumption of the model is that these two 
decisions are made in two different stages. The first stage of Cragg's model is a probit model to identify the determinants of adoption, and the second stage is a truncated regression model for identifying the determinants of the intensity of adoption (Cragg, 1971). Let $\boldsymbol{d}_{\boldsymbol{i}}^{*}$ is the latent variable describing a HH's decision to adopt, $\boldsymbol{y}_{\boldsymbol{i}}^{*}$ is the latent variable describing its decision on the intensity of adoption, and $\boldsymbol{d}_{\boldsymbol{i}}$ and $\boldsymbol{v}_{\boldsymbol{i}}$ are their observed counterparts, respectively.

Based on the specification by Cragg (1971) and Peter (2005), the two hurdles for a household can be written as:

$$
\begin{gathered}
d_{i}^{*}=\alpha z_{i}+u_{i} \\
\mathrm{v}_{\mathrm{i}}^{*}=\beta \mathrm{x}_{\mathrm{i}}+\epsilon_{\mathrm{i}} \cdots
\end{gathered}
$$

Where,

$$
d_{i}=\left\{\begin{array}{l}
1, \text { ifd }_{i}^{*}>0 \\
0, i f d_{i}^{*} \leq 0
\end{array} \text { andv }_{i}=\left\{\begin{array}{c}
\mathrm{v}_{i}^{*}, i \mathrm{v}_{i}^{*}>0 \text { andd }_{i}^{*}>0 \\
0, \text { ifotherwise }
\end{array}\right.\right.
$$

Where $\boldsymbol{z}_{\boldsymbol{i}}$ is the vector of variables explaining whether a $\mathrm{HH}$ adopts physical SWC practices, $\boldsymbol{x}_{\boldsymbol{i}}$ is a vector of variables explaining the level of adoption, and $\boldsymbol{u}_{\boldsymbol{i}}$ and $\boldsymbol{\varepsilon}_{\boldsymbol{i}}$ are the error terms. The dependent variable in the first stage is the HH's adoption decision. This variable is binary in nature, taking numeric values 1 for adopters, and 0 for non-adopters. In the second stage, the dependent variable is the proportion of area covered by physical SWC practices. In the Double hurdle model, both hurdles have equations associated with them, incorporating the effects of $\mathrm{HH}$ characteristics and circumstances. Such explanatory variables may appear in both equations and either of them (Teklewold et al., 2006). According to Carroll et al. (2005), equations ${ }^{2}$ and ${ }^{3}$ are assumed to be independent, and therefore the error terms are randomly and independently distributed, $\boldsymbol{v}_{\boldsymbol{i}} \sim N(0,1)$ and $\boldsymbol{\varepsilon}_{\boldsymbol{i}}$ $\sim N\left(0, \sigma \varepsilon^{2}\right)$.

The log-likelihood function for the Double hurdle model is:

$$
\log \mathrm{L}=\sum \ln \left[1-\Phi\left(\alpha \mathrm{Z}_{\mathrm{i}}\left(\frac{\beta \mathrm{X}_{\mathrm{i}}}{\sigma}\right)\right]+\sum \ln \left[\Phi\left(\alpha \mathrm{Z}_{\mathrm{i}}\right) \frac{1}{\sigma} \phi\left(\frac{\mathrm{Y}_{\mathrm{i}}-\beta \mathrm{X}_{\mathrm{i}}}{\sigma}\right)\right]\right.
$$

Where $\boldsymbol{\Phi}$ and $\boldsymbol{\phi}$ are the standard normal cumulative distribution function and density function, respectively. The log-likelihood function is estimated using the maximum likelihood estimation (MLE) technique. The double hurdle model is reduced to the Tobit model when the probit mechanism ( $\left.\boldsymbol{d}_{\boldsymbol{i}}^{*}>0\right)$ is absent in Equation 2. This can also be seen in 
the log-likelihood function presented in Equation 3 when $\boldsymbol{\Phi}\left(\boldsymbol{Z}_{i} \boldsymbol{\alpha}\right)=1$. The Tobit model arises if $\boldsymbol{\alpha}=\boldsymbol{\beta} / \boldsymbol{\sigma}$ and $\mathbf{x}=\mathbf{z}$ (Martinez-Espineira, 2006).

The absence of the probit mechanism implies that the decision about adoption and level of adoption is made simultaneously. We also develop a Tobit model and do a standard likelihood ratios test between the Tobit and double hurdle model to know how these decisions are made. Following Gujarati (2003), the Tobit model for our specific case can be written as:

$$
\mathrm{y}_{\mathrm{i}}=\left\{\begin{array}{c}
\mathrm{y}_{\mathrm{i}} \text { iflandallocatedforphysicalsWCpractices } \\
\text { 0otherwise }
\end{array}\right.
$$

Where $\boldsymbol{\beta}_{0} \ldots \boldsymbol{\beta}_{\boldsymbol{x}}$ are the unknown parameters to be estimated and $\boldsymbol{x}_{\mathbf{1 i}} \ldots \boldsymbol{x}_{\boldsymbol{k} \boldsymbol{i}}$ are the same set of explanatory variables used in the second stage of the Cragg model. Using MLE, the Tobit model is estimated. According to Maddala (1992), the likelihood function for the Tobit model can be written as:

$$
L=\prod_{V_{i}>0} \frac{1}{\sigma} f\left(\frac{y i-\beta x_{i}}{\sigma}\right) \prod_{V_{i}<0} F\left(-\frac{\beta X_{I}}{\sigma}\right)
$$

By maximizing the function concerning $\beta$ and $\sigma$, we get the MLE estimates of these parameters. As the Tobit model is nested in the Cragg model, it is possible to compare these two models through a standard likelihood ratio test when the determinants in both hurdles are the same (Buraimo et al., 2010). The test statistics can be computed as in Greene (2000):

$$
\Gamma=-2\left[\ln L_{T}-\left(\ln L_{P}+\ln L_{T R}\right)\right] \tilde{X}_{k^{2}}
$$

Where, $\Gamma$ = likelihood ratio statistic; In= natural logarithm, $L_{T} L_{P}$ and $L_{T R}$ are log-likelihoods of the Tobit, Probit, and Truncated regression models, respectively, $X^{2}=$ chi-square statistic

and $\mathrm{k}$ is the number of independent variables in the equations. Rejection of the null hypothesis $\left(\Gamma>X^{2}{ }_{k}\right.$ ) argues for the superiority of the double hurdle model over the Tobit model and establishes that the decisions about adoption and intensity adoption are made in two different stages.

\section{Results And Discussion}

\subsection{Descriptive Statistics Results} 3.1.1. The adoption of physical SWC practices 
From the total sample, respondents around 71(47.33\%) of HHs adopt physical SWC practices Whereas $79(52.67 \%)$ of respondents didn't adopt physical SWC practices. As shown in Figure 2, adopter HHs in the study area applied different physical SWC practices on their farm plot to minimize soil loss, increase soil fertility and improve the productivity of degraded lands. These practices include soil bund, fanya juu, cutoff drain, and waterways. However, it is not usual to see stone bunds or stone-faced bunds due to the scarcity of stone, which is attributable to the geological feature of the study area. The result shows that $29.11 \%$ of sample respondents applied soil bund to decrease soil erosion problems. Those indicated that soil bund is the most widely used physical SWC practice in the study area than the others.

Next to the soil bund, sample respondents applied a cut-off drain though it prevents loss of seeds, fertilizers, manure, and soil due to water flowing onto the plot from uphill. The result of this study revealed that $26.58 \%$ of respondents adopted cut-off drain. Likewise, $25.32 \%$ of sample respondents in the study area adopted fanya juu to decreases the speed of runoff more than a soil bund. On the other way, $18.99 \%$ of sample respondents constructed waterways in their farm plots to safely transport runoff water from a field via natural field drainage ways.

\subsubsection{Sustainability of physical SWC practices}

For ensuring, the sustainability and beneficial impacts of the implemented physical SWC practices on productivity, SWC practices have to be regularly maintained. Therefore, the effort of the HHs to maintain implemented physical SWC practices indicates their acceptance of the practices. For this purpose, respondent $\mathrm{HHs}$ answer to some questions concerning the maintenance of implemented physical SWC practices.

As presented in Table 3, 40 percent of respondents maintain physical SWC practices regularly, while 7.33 percent of HHs did not. However, 52.67 percent of respondents did not have introduced physical SWC practices in their plot.

Following this, respondents were asked to list the main reasons that discourage them from maintaining SWC practices. About $3.33 \%$ of the respondents reported that lack of skill and knowledge is one factor to use the conservation practices continuously (Table 5). $2.22 \%$ and $6.67 \%$ of the respondents reported a lack of support and shortage of labor to maintain conservation practices, respectively. In addition to the above reason, from the focus group discoutions the reasons for not maintaining SWC practices were minimum understanding of the severity of erosion and low knowledge of $\mathrm{HHs}$ on conservation practices. 
Table 3

Maintenance of physical SWC practices in the study area

\begin{tabular}{|lll|}
\hline Did you maintain SWC Practices? & $\begin{array}{l}\text { Frequency } \\
\text { (Freq.) }\end{array}$ & $\begin{array}{l}\text { Percent } \\
\text { (\%) }\end{array}$ \\
\hline Yes & 60 & 40 \\
No & 11 & 7.33 \\
I don't have physical SWC practices & 79 & 52.67 \\
Lack of skill and Knowledge & 3 & 3.33 \\
Lack of support & 2 & 2.22 \\
Shortage of household labor & 6 & 6.67 \\
\hline Source: Survey result, 2021 & & \\
\hline
\end{tabular}

\subsubsection{The advantages of physical SWC practices in the study area}

As Figure 3 shows, the advantage respondents obtained from adopting physical SWC practices. The HHs rank first reduced soil erosion (38.46\%), improved crop yield (30.77\%), controls flood (16.92\%), and increased water availability (13.85\%), respectively. During the group discussion and informant interview held with HHs, the effectiveness of SWC practices emphasized as they observed better growth and development of crops with conservation technologies where fertile sediment were trapped.

\subsubsection{The intensity of adoption of physical SWC practices}

As Table 4 shows, the mean proportion of area covered by physical SWC practices of adopter respondent HHs were around $57.23 \%$ with the standard deviation of $11.66 \%$ in the study areas. As well as, the maximum and minimum proportion of area covered by physical SWC practices were $77.77 \%$ and $28.57 \%$.

Table 4

The intensity of adoption of physical SWC practices

\begin{tabular}{|l|cccc|}
\hline & Mean & Std. Dev & Min & Max \\
\hline The proportion of area covered by physical SWC practices (\%) & 57.23 & 11.659 & 28.57 & 77.77 \\
\hline Source: Own surveyed data 2021 & & & & \\
\hline
\end{tabular}

\subsubsection{Descriptive statistics for dummy variables}


As indicated in Table 5, from the total 150 sample respondents, about 123(82\%) of sample respondents were male HHs whereas $27(18 \%)$ were female HHs. Among the total sample respondents, $62(87.32 \%)$ male HHs and $9(12.68 \%)$ female HHs adopt physical SWC practices. Whereas $61(77.22 \%)$ male HHs and $18(22.78 \%)$ female HHs were non-adopters of physical SWC practices. The $X^{2}$ - test result of sex distribution between the adopters and non-adopters of physical SWC practices was insignificant.

As explained in Table 5 the participation of HHs in off-farm activities harms the probability adoption of physical SWC practices (Million et al., 2019). The chi-square test was employed to test association between off-farm activity participation and adoption of physical SWC practices. The result indicates that from the total $49(39.33 \%)$ off-farm activities participant $\mathrm{HHs}$, 18(36.73\%) were physical SWC practice adopters while $31(63.27 \%)$ were non-adopters. The $X^{2}$-test result shows that, there is a statistically significant difference between adopters and non-adopters in terms of off-farm activity participation.

HHs awareness of soil erosion problems on their plot, causes, and consequences of the soil erosion problems will increase, the probability use of SWC practices. As various studies indicated, the perception about soil erosion problem by HHs is one of the determinant factors for HHs to make decisions on SWC investment. The perception of sample respondents on soil erosion has paramount importance to adopt physical SWC practices. The survey result indicated that about 42 percent of the respondents perceived soil erosion as a problem on their plots. Additionally, the respondents were asked to rank the degree of soil erosion problems on their plots. As surveyed result shows, 24, 34.67, and 41.33 percent of respondents ranked, the degree of soil erosion problems low, medium, and high, respectively.

Among the total $63(42 \%)$ respondents who perceived soil erosion as a problem, $30(73.02 \%)$ were physical SWC adopters, while 33(26.98\%) were non-adopters. That indicates most respondents who perceived soil erosion as a problem adopt physical SWC practices in their farm plot to minimize soil loss and enhance soil fertility compared to its counterpart. On the other hand, among the respondents who lack the perception of soil erosion problems, 42 (28.74\%) were physical SWC practice adopters, while $46(71.26 \%)$ were non-adopters. The $X^{2}$ - test result shows that, there is a statistically significant difference between adopters and non-adopters in terms of perception of soil erosion problems. That indicates awareness creation about the soil erosion problems is very important to increase the adoption of physical SWC practices.

The slope of the plots expands problems of soil erosion. Therefore, there is a relationship between slope and the adoption of physical SWC practices. The degree of soil erosion influences the variation plot gradient. As a result in Table 5 indicated 17.33, 32.67, and 50 percent of the respondents' farm plots were flat, gentle, and steep slope, respectively. The cross-tabulation result indicates that $2.67,34.67$, and 62.67 percent of flat, gentles, and steeps slope plot owner HHs were physical SWC Practice adopters.

While 32, 30.67, and 37.33 percent of flat, gentle, and steep slope farm plot owner HHs did not adopt physical SWC practices. These indicate that respondent HHs who own gentle or steep slope farm plots adopted physical SWC practices because these types of plots are prone to soil erosion problems. The $X^{2}$ - 
test result shows that, there is a statistically significant difference between adopters and non-adopters of physical SWC practices in terms of the slope of the farm plot. From this result, we can conclude that gentles or steeps slope plots have a positive relationship with the adoption of physical SWC practices.

HHs those who are members in different local organizations are assumed to have more access to information and better interpret and use the available information related to new technologies. As presented in Table 5, from the total $121(80.67 \%)$ member HHs, 61(50.41\%) were adopters, whereas $60(49.59 \%)$ are non-adopters. The $X^{2}$-test result shows that, there is insignificant difference between adopters and non-adopters in terms of membership in different local organizations.

Training is essential to fill knowledge and information gaps. Both governmental and non-governmental organizations have provided training for $\mathrm{DAs}$ and $\mathrm{HHs}$ concerning natural resource conservation through field visits, workshops, and experience sharing. The involvement of $\mathrm{HHs}$ in conservation-related pieces of training has importance for the adoption of physical SWC practices. As a result in Table 5 showed $121(80.67 \%)$ of the respondent HHs got training on SWC practices; whereas, $29(19.33 \%)$ of respondents did not get training on SWC practices. Out of the trained respondent HHs, $68(56.20 \%)$ were adopters, while $53(43.80 \%)$ were non-adopters. The $X^{2}$-test result shows that, there is a statistically significant difference between adopters and non-adopters in terms of training on SWC practices. 
Table 5

Descriptive statistics results of dummy and categorical variables

\begin{tabular}{|c|c|c|c|c|c|c|}
\hline \multirow[t]{3}{*}{ Variables } & \multirow[t]{3}{*}{ Categories } & \multicolumn{4}{|c|}{ Adoption of Physical SWCPs } & \multirow[t]{3}{*}{ x2-value } \\
\hline & & \multicolumn{2}{|c|}{$\begin{array}{l}\text { Adopter } \\
(n=71)\end{array}$} & \multicolumn{2}{|c|}{$\begin{array}{l}\text { Non-adopter } \\
(n=79)\end{array}$} & \\
\hline & & Freq. & $\%$ & Freq. & $\%$ & \\
\hline \multirow[t]{2}{*}{ Sex of $\mathrm{HH}$} & Male & 62 & 50.41 & 61 & 49.59 & 2.59 \\
\hline & Female & 9 & 33.33 & 18 & 66.67 & \\
\hline \multirow[t]{2}{*}{ Off-farm activities } & Yes & 18 & 36.73 & 31 & 63.27 & $3.28 *$ \\
\hline & No & 53 & 52.48 & 48 & 47.52 & \\
\hline \multirow[t]{2}{*}{ Perception of Soil Erosion problem } & Yes & 30 & 73.02 & 33 & 26.98 & $28.74^{\star \star *}$ \\
\hline & No & 41 & 28.74 & 46 & 71.26 & \\
\hline \multirow[t]{3}{*}{ Slope } & Flat & 2 & 7.69 & 24 & 92.31 & $23.61^{\star \star *}$ \\
\hline & Gentle & 26 & 53.06 & 23 & 46.94 & \\
\hline & Steep & 47 & 62.67 & 28 & 37.33 & \\
\hline \multirow[t]{2}{*}{ Membership in local organizations } & Yes & 61 & 50.00 & 60 & 50.00 & 2.38 \\
\hline & No & 10 & 34.48 & 19 & 65.52 & \\
\hline \multirow[t]{2}{*}{ Training on SWC practices } & Yes & 68 & 56.20 & 53 & 43.80 & $19.73^{\star * *}$ \\
\hline & No & 3 & 10.34 & 26 & 89.66 & \\
\hline
\end{tabular}

Source: Own surveyed data of 2021

\subsubsection{Descriptive statistics for continuous variables}

As indicated in Table 6, the average age of HHs in the study area was 46.31 with a standard deviation of 9.96 of which, physical SWC practices adopters were 43.28 years, and non-adopters were 49.01 years. The result of t-test shows that there is statistically significant difference between adopters and nonadopters at a $1 \%$ significance level in terms of age of the HHs.

Education can influence the adoption of newly introduced technologies and innovations. Hence, educated $\mathrm{HHs}$ expected to be in better position to get and use information that contributes to adopting physical SWC practices. As presented in Table 6, the average educational level in schooling years of adopter HHs 
were 7.80 years with a standard deviation of 1.73 whereas non-adopter, $\mathrm{HHs}$ was 4.84 years with a standard deviation of 2.01. The t-test result indicated that, there was a statistically significant mean difference between adopters and non-adopters at a $1 \%$ in terms of the education level of the HHs in the study area. That means adopters have a higher level of education compared to non-adopters.

To standardize the analysis number of livestock was converted to tropical livestock unit (TLU) as the conversion factors given in Appendix Table 1. The result in Table 6 shows the average livestock ownership of adopter HHs was 4.02, while 5.03 for the non-adopter HHs with standard deviations of 1.49 and 2.02, respectively. The t-test result indicated that the mean livestock holding difference between adopters and non-adopters was statistically significant at a $1 \%$ significance level. This show that there is a statistical mean difference between adopters and non-adopters in terms of livestock holding.

To compute family sizes, the standard conversion factor given in Appendix Table 2 used. The result of Table 6 showed that, the average family size of adopter HHs was 3.04 and non-adopter HHs was 2.06 with standard deviations of 0.75 and 0.83 , respectively. The t-test result indicates that, there is a statistically family size mean difference between adopter and non-adopter $\mathrm{HHs}$ at a $1 \%$ significance level. That means there is a statistical mean difference between adopters and non-adopters in terms of family size. As presented in Table 6, the average plot size of adopter HHs was 3.60 ha with a standard deviation of 1.38 ha, while the average land allocation of non-adopters was 1.97 ha with a standard deviation of $1.15 \mathrm{ha}$. The t-test result indicated a statistical mean plot size difference between adopters and nonadopters of $\mathrm{HHs}$ at a $1 \%$ significance level. This show that larger plot sizes might lead to intensely adopt physical SWC practices.

The result in Table 6 showed that the average distance from homestead to the farm plot for adopter HHs was 18.27 walking minutes with a standard deviation of 9.03 , while 20.55 walking minutes with a standard deviation of 12.34 for non-adopting HHs. Extension contact refers to the number of contacts respondent $\mathrm{HHs}$ made with DAs per month. Based on survey data as shown in Table 6, the average extension contacts of adopter HHs respondent made with DAs was 5.80 days, and non-adopters were 2.88 days with a standard deviation of 1.74 and 1.91 , respectively. The t-test result indicated that statistical mean of extension contact difference between adopters and non-adopters of $\mathrm{HHs}$ at a $1 \%$ significance level. 
Table 6

Descriptive statistics of continuous variables

\begin{tabular}{|c|c|c|c|c|c|}
\hline \multirow[t]{3}{*}{ Variables } & \multicolumn{5}{|c|}{ Adoption of Physical SWC Practices } \\
\hline & \multicolumn{2}{|c|}{$\begin{array}{l}\text { Adopter } \\
(n=71)\end{array}$} & \multicolumn{3}{|c|}{$\begin{array}{l}\text { Non-adopter t-test } \\
(\mathrm{n}=79)\end{array}$} \\
\hline & Mean & Std. Dev & Mean & Std. Dev & \\
\hline Age of $\mathrm{HH}$ & 43.60 & 9.64 & 49.01 & 9.59 & $3.45^{\star \star \star}$ \\
\hline Education level of $\mathrm{HH}$ & 7.80 & 1.73 & 4.84 & 2.01 & $-9.13^{\star \star \star}$ \\
\hline Family Size & 3.04 & 0.75 & 2.06 & 0.83 & 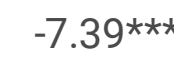 \\
\hline Total livestock (TLU) & 4.02 & 1.49 & 5.03 & 2.02 & $2.85^{\star \star \star}$ \\
\hline Plot Size (ha) & 3.60 & 1.38 & 1.97 & 1.15 & $-7.20 * \star \star$ \\
\hline Distance (Min) & 18.27 & 9.03 & 20.55 & 12.40 & 1.24 \\
\hline Number of extension contact & 5.80 & 1.74 & 2.88 & 1.91 & $-9.18^{\star \star \star}$ \\
\hline
\end{tabular}

Source: Own surveyed data of 2021

\subsection{Result of econometric models}

Double hurdle model was used to estimate the determinants of adoption and intensity adoption of physical SWC practices. Accordingly, explanatory variables were checked for problems of multicollinearity, and heteroscedasticity. Following Gujarati, 1995 the problem of multicollinearity for continuous explanatory variables was investigated using a technique of variance inflation factor (VIF). The values of VIF were less than ten. As a result, there is no serious problem of multicollinearity.

To observe the degree of association between dummy explanatory variables contingency coefficient was computed. Contingency coefficient is a chi-square-based measure of association, where a value of 0.75 or above indicates a stronger relationship between explanatory variables (Healy, 1984). It was checked, and it is less than 0.75 . To avoid heteroscedasticity robust standard error is estimated. Log-likelihood test of Double hurdle versus Tobit model: $\Gamma=233.198>\chi 2(14)=29.141$, the test statistics of Double hurdle versus Tobit model indicate the rejection of Tobit model. Therefore, Double hurdle is an appropriate model than Tobit model for this study. It shows that HHs on the adoption decision and intensity of adoption of physical SWC practices made in two separate stages.

\subsubsection{Determinants of the adoption of physical SWC practices (First hurdle)}


Sex of the household head: This variable influenced the probability adoption of physical SWC practices positively and significantly at a $5 \%$ significance level. The model result confirmed that the probability of being male $\mathrm{HH}$ increases, the adoption of physical SWC practices. Female HHs spent their time in domestic activities and responsibilities. Thus, they have no sufficient time to get extension services about SWC practices. In addition, male HHs have a higher chance to involve in SWC practices since constructing and maintaining physical SWC practices demand much labor. Consistent with this result, the studies by Solomon (2016), Daniel and Mulugeta (2017), Zewditu (2019) obtained that male HHs have a higher chance to involve in SWC practices since constructing and maintaining SWC practices demand much labor. This finding is opposing with previous studies by (Fikadu and Engdawork, 2019; Olawuiy and Mushunye, 2019).

Age of the household head: This variable affected the probability adoption of physical SWC practices negatively and significantly at a $1 \%$ significance level. The probit regression result confirmed that, as the age of HHs increases, the acceptance level of HHs about the introduced physical SWC practices decreased. This implies that younger HHs expended more effort on physical SWC practices relative to older ones. Therefore, younger HHs have the willingness to adopt the introduced physical SWC practices compared to older HHs. This result was similar to the studies by Aneley et al. (2007), Daniel and Mulugeta (2017), and Mountain and Park (2018). They reported that HHs with younger age have a higher ability to adopt SWC practices. However, this finding is contrary to the results by Fikru (2009), Nelson et al. (2017), Olawuiy and Mushunye (2019), and Mehariw (2020) that verified, age of HHs positively influence the adoption of SWC practices.

The education level of household head: This variable influenced the probability adoption of physical SWC practices positively and significantly at a $1 \%$ significant level. The model result confirmed that, as $\mathrm{HHs}$ get a better education level, their attitude towards the probability adoption of physical SWC practice increased. These implied that HHs with relatively better education levels are more likely to adopt physical SWC practices, and they can anticipate the consequences of soil erosion problems than others. This result is in line with the studies of (Fikru, 2009; Melkie, 2016; Daniel and Mulugeta, 2017; Belete, 2017; Muluken et al., 2020; kalkidan, 2021), which stated that a better education level of HHs has a positive relationship with the adoption of SWC practices. This finding is inconsistent with the previous study of Asnake et al. (2018).

Household heads perception about soil erosion problems: The model result in Table 7 showed this variable affected the probability adoption of physical SWC practices positively and significantly at a $5 \%$ significance level. The Double hurdle model result indicated that as HHs perceived their plots are prone to soil erosion problems, they like more to adopt physical SWC practices than those who did not perceive soil erosion problems. Therefore, better awareness of HHs about soil erosion problems contributes to the sustainable use of the introduced SWC practices. This result is in line with the studies by (Zewditu, 2019; Million et al., 2019), which argued that the perception of HHs on soil erosion problems increases the probability adoption of SWC practices. 
Number of extension contacts: This variable positively and significantly influenced the adoption of physical SWC practices at a $5 \%$ level of significance. The model result revealed that an increase in the frequency of extension contact increases the probability adoption of physical SWC practices. This implies that $\mathrm{HH}$ who have close contact with extension agents can develop awareness and understanding of the soil erosion problem and become encouraged to adopt physical SWC practices. This finding is similar to studies by Aneley et al. (2007), Zewditu (2019), and Muluken et al. (2020) that state extension services have a positive effect on SWC practice.

Training on SWC practices: This variable affected the probability adoption of physical SWC practices positively and significantly at a $10 \%$ significance level. The probit model result showed that HHs participation in training related to SWC practice increases the adoption of physical SWC practices. These implied that $\mathrm{HHs}$ who take training acquire adequate and recent information and technical support about the implementation and relevance of SWC practices. Therefore, they improve their awareness of the participation of physical SWC practices and facilitate the uses of conservation measures. This result is in line with the findings of Addisu et al. (2015), Belete (2017), Birtukan et al. (2020), and Temitope et al. (2021). They reported that access to training has a positive relationship with the adoption of SWC practices. However, this result contradicts a finding of (Fikru, 2009) which stated that training on SWC practice negatively affects the probability adoption of soil or stone bund and tree plantations.

Family size: As regression results in Table 7 indicated, this variable influenced the probability adoption of physical SWC practices positively and significantly at a 5\% significance level. The Probit model result confirmed that HHs with larger family sizes are more like to adopt physical SWC practices compared to the others. It implies that larger families have a better labor force to construct labor-intensive SWC practices, which are more labor demanding than biological measures. This study agreed with the findings of Adissu et al. (2015), Belete (2017), Asnake et al. (2018), Agere et al. (2020), Mehariw (2020), Gizachew and Birhanu (2021), and Temitope et al. (2021). They confirmed that a large family size could provide the required labor for constructing and maintaining conservation practices.

\subsubsection{Determinants of the intensity adoption of physical SWC practices (Second Hurdle)}

The second hurdle of the Double hurdle model measured the intensity adoption of physical SWC practices among adopting HHs. The intensity adoption of physical SWC practice is significantly affected by four explanatory variables. As shown in Table 9, the result of the second hurdle indicates that variables such as; plot size, steep slope, training, and number of extension contact are the significant factors that affect the intensity adoption of physical SWC practices.

Plot size: As result in Table 9 indicated, this variable affected the intensity adoption of physical SWC practices positive and significantly at a $5 \%$ significance level, which implies that an increase in plot size leads to an increase in the intensity adoption of physical SWC practices. The computed result indicated that a unit increase in plot size increases the intensity adoption of physical SWC practices by 1.17 percent. The HHs that allocated large plot size has more opportunities to control soil erosion by covering 
their land by physical SWC practices than those who own less plot size. This finding is congruent with previous studies conducted by (Aneley et al., 2007; Olawuyi and Mushanji, 2019; Eyerusalem, 2017; Amsalu and Alebachew, 2020).

Slope of the plot: The probability of steep slope plot affected the intensity adoption of physical SWC practices positively and significantly at a $1 \%$ significance level. The model result indicated that $\mathrm{HHs}$ having steep slope plots increases their intensity adoption of physical SWC practices by 18.93 percent respectively. This implies that, as the HHs plot inclines, the implementation of SWC practices is very intense to respond to the urgent soil erosion problems. Hence, steeper slopes increase the intensity of adopting physical SWC practices. The result is in line with the studies by (Berhanu and Scott, 2003; Aneley et al., 2007; Mengistu, 2012; Eyerusalem, 2017) argued that slope of the plot is one of the factors that significantly influence the intensity adoption of conservation practices.

Training on SWC practices: This variable is positively and significantly affects the intensity adoption of physical SWC practices at a $1 \%$ significance level. The model result indicates that $\mathrm{HH}$ who participates in training are more likely to apply a significant amount of land to physical SWC practices than those HHs who did not participate. Compared to HHs who did not participate in training, the intensity adoption of physical SWC practices increased, by 5.4 percent for HHs who participates in training. This result is similar with studies of (Tesfaye, 2017; Fikadu and Engdawork, 2019) which argued that training influences the intensity adoption of agricultural technology positively.

Number of extension contact: This variable influenced the intensity adoption of physical SWC practices positively and significantly at a $1 \%$ significance level. The truncated model result confirmed that as the number of extension contact increases, the intensity adoption of physical SWC practices increased by 3.4 percent. This implies that frequent contact with development agents has the better technical skill to manipulate the introduced physical SWC practices. The HHs who have more contact with extension workers would acquire more information related to the benefit of SWC, the techniques of implementation, and maintenance. Also, it increases the probability of developing up-to-date information on the new agricultural technologies. This finding is in line with the research result reported by Aneley et al. (2007), Eyerusalem (2017), Fikadu and Engdawork (2019), and Amsalu and Alebachew (2020). 
Table 7

Cragg's Double hurdle model results

\begin{tabular}{|c|c|c|c|c|}
\hline \multirow[t]{2}{*}{ Variables } & \multicolumn{2}{|c|}{$\begin{array}{l}\text { First hurdle } \\
\text { (Adoption) }\end{array}$} & \multicolumn{2}{|c|}{$\begin{array}{l}\text { Second hurdle } \\
\text { (Intensity) }\end{array}$} \\
\hline & Coef. & Std. Err. & Coef. & Std. Err. \\
\hline Sex of the $\mathrm{HH}$ & $0.76^{\star *}$ & 0.353 & 0.87 & 1.501 \\
\hline Age of the $\mathrm{HH}$ & $-0.07 * \star \star$ & 0.022 & 0.02 & 0.049 \\
\hline Education level of $\mathrm{HH}$ & $0.31 * \star \star$ & 0.088 & 0.38 & 0.536 \\
\hline Family size & $0.51^{\star *}$ & 0.21 & -0.198 & 0.817 \\
\hline Distance from home to the farm plot & 0.01 & 0.015 & -0.06 & 0.052 \\
\hline Plot size & -0.08 & 0.193 & $1.17 \star \star$ & 0.512 \\
\hline Steep slope & 0.24 & 0.422 & $18.9 * \star \star$ & 2.824 \\
\hline Perception of soil erosion & $0.79 * *$ & 0.329 & 1.60 & 1.103 \\
\hline Training on SWC practices & $1.00 *$ & 0.523 & $5.37^{\star \star \star}$ & 1.869 \\
\hline Number of extension contact & $0.25^{\star \star}$ & 0.105 & 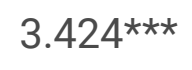 & 0.635 \\
\hline Off-farm activity participation & -0.23 & 0.338 & -0.13 & 0.879 \\
\hline Membership to local organization & -0.43 & 0.33 & & \\
\hline Livestock owenership & -1.00 & 0.091 & & \\
\hline Constant & -2.686 & 1.429 & 10.14 & 5.12 \\
\hline Number of obs. $=150$ & \multicolumn{4}{|c|}{ Limit: lower $=0$} \\
\hline Wald $C h i^{2}(14)=80.62$ & \multicolumn{4}{|c|}{ Upper $=+$ inf } \\
\hline $\mathrm{P}>C h i^{2}=0.0000$ & \multicolumn{4}{|c|}{ Number of obs $=71$} \\
\hline Log likelihood = -37.011 & \multicolumn{4}{|c|}{${\text { Wald } C h i^{2}(12)=873.05}$} \\
\hline Pseudo $R^{2}=0.6433$ & \multicolumn{4}{|c|}{ Log likelihood $=-204.059$} \\
\hline & \multicolumn{4}{|c|}{ Prob $>$ chi2 $=0.0000$} \\
\hline
\end{tabular}

Source: Own estimation result of 2021

\section{Conclusions}


The study identifies the determinants of the adoption and intensity adoption of physical SWC practices in Goromti watershed Ambo Woreda of Oromia region, Ethiopia with the specific objectives of identifying factors affecting adoption and intensity adoption of physical SWC practices in the study area. The analysis was made using descriptive statistics like chi-square and t-tests to compare the variables with $\mathrm{HHs}$ adoption decision on physical SWC practices and econometric analysis by Double hurdle model to analyze the factors that affect the probability of adoption and intensity adoption of physical SWC practice. The first stage of Double hurdle model analysis indicated that sex, age, education level, frequency of extension contact, perception of soil erosion problem, family size, and training significantly determine the adoption of physical SWC practices in the study area. The second stage of Double hurdle model indicates that plot size, gentle slope, steep slope, training, and frequency of extension contact significantly determine the intensity adoption of physical SWC practices. In general, the study concluded that the adoption and intensity adoption of physical SWC practices were driven by a host of demographic, physical, socio-economic, and institutional factors. Hence, it is believed that these findings will be an important achievement for future research and policy formulation in Ethiopia as it provides first-hand information about factors affecting the adoption and intensity adoption of physical SWC practices in the study area.

\section{List Of Abbreviations}

$\begin{array}{ll}\text { AGRA } & \text { Alliance Green Revolution in Africa } \\ \text { AWANRO } & \text { Ambo Woreda Agricultural and Natural Resource Office } \\ \text { CSA } & \text { Central Statistical Agency } \\ \text { EPRDF } & \text { Ethiopian People Republic Democratic Front } \\ \text { FAO } & \text { Food and Agricultural Organization of the United Nations } \\ \text { FFW } & \text { Food-for-Work Program } \\ \text { GDP } & \text { Gross Domestic Product } \\ \text { GIS } & \text { Geographical Information System } \\ \text { GoE } & \text { Government of Ethiopia } \\ \text { MM } & \text { Millimetre } \\ \text { M.a.s.1 } & \text { Mean Above Sea level } \\ \text { MLE } & \text { Maximum Likelihood Estimation } \\ \text { MoA } & \text { Ministry of Agriculture } \\ \text { SLM } & \text { Stainable Land Management } \\ \text { SPSS } & \text { Statistical Package for Social Sciences } \\ \text { SRCCL } & \text { Statistical Report on Climate Change and Land } \\ \text { SWC } & \text { Soil and Water Conservation Practices } \\ \text { TLU } & \text { Tropical Livestock Unit } \\ \text { UNCCD } & \text { United Nations Convention to Combat Desertification } \\ \text { WFP } & \text { World Food Program } \\ \text { WOCAT } & \text { World Overview of Conservation Approaches and Technologies }\end{array}$

\section{Declarations}


Competing interests: There is no competing interest to this manuscript

Authors' contribution: co-authors for this manuscript contributed advisory service for the thesis during thesis work

Availability of the data: data for this manuscript is available at any time.

Funding: the correspondent authors' sponsored the research sins she is self-sponsored

\section{ACKNOWLEDGMENTS}

First and foremost I would like to thank the Almighty God for giving me the strength, patience, and knowledge that enabled me to efficiently and effectively tackle this study. I express my genuine gratitude to my major advisor, Dr. Aman Rikitu for his immense and interminable encouragement, consistent guidance and critical remarks from the very beginning of the proposal initiation up to the final write up and moral encouragement, giving directions and valuable comments.

\section{Authors' Declaration}

I declare that this thesis is my own work. I have followed all ethical and technical principles of scholars in the preparation, data collection, data analysis and compilation of the Thesis. Any scholarly matter that is included in the Thesis has been recognition through citation.

\section{References}

Addisu Damtew Atnafe, Husen Maru Ahmed, and Demeku Mesfin Adane. (2015). Determinants of adopting techniques of soil and water conservation in Goromti Watershed, Western Ethiopia. Journal of Soil Science and Environmental Management 6 (6), 168-177.

Agere Belachew, Wuletaw, M., and Kavitha, N. (2020). Factors influencing adoption of soil and water conservation practices in the northwest Ethiopian highlands. International Soil and Water Conservation Research, 8(1), 80-89.

AGRA (Alliance Green Revolution Africa). (2018). Africa Agriculture Status Report: Catalyzing Government Capacity to Drive Agricultural Transformation (6), Nairobi, Kenya.

Akalu Teshome, Jan de Graaff, and Menale Kassie. (2016). Household-Level Determinants of Soil and Water Conservation Adoption Phases: Evidence from North-Western Ethiopian Highlands. Environmental Management 57(3), 620-636.

Alemayehu Keba, Adeba Gemechu Gobena, and Admassu Tesso. (2019). Factor affecting adoption and intensity of use of improved maize varieties: The case of Kiremu District Oromia Regional State, Ethiopia. Agricultural Science Research Journal 10(2), 41-54. 
Amsalu Dachito Chigeto, and Alebachew Angelo. (2020). Farmers' technology adoption decision and use intensity in the agricultural sector: a case of Masha district. International Journal of Commerce and Finance, 6(2), 1-17.

Andrew, M. (1989). A double hurdle model of cigarette consumption. Journal of Applied Econometrics 4(1), 23-39.

Asnake Mekuriaw, Andreas, H., Gete, Z., and Hans, H. (2018). Factors influencing the adoption of physical soil and water conservation practices in the Ethiopian highlands. International soil and water conservation research, 6(1), 23-30.

AWARDO (Ambo Wereda Agricultural and Natural Resource Office). (2020). Annual report on Goromti Watershed, Unpublished.

Belete Limani Kerse. (2017). Factors affecting adoption of soil and water conservation practices in the case of Damotawatershed, Wolaita zone, Southern, Ethiopia. International Journal of Agricultural Science Research 7(1), 001-009.

Birhan Asmame Miheretu, and Assefa Abegaz Yimer. (2017). Determinants of farmers' adoption of land management practices in Gelana sub-watershed of Northern highlands of Ethiopia. Ecological Processes, 6(19).

Birtukan Dufera, Dharmnder Kumar Dube, and Abebe Aschalew. (2020). Socio-Economic Impacts, and Factors Affecting Adoption of Watershed Management Practices between the Treated and Untreated Micro-Watersheds in the Chiracha sub-Watershed of Ethiopia. Palarch's Journal of Archaeology of Egypt/Egyptology 17(9). ISSN 1567-214x

Bunyad, H., Jonathan, L., Herath, M., and Lan, M. (2017). Water security for productive economies: Applying an assessment framework in Southern Africa. Physics and Chemistry of the Earth, 100, 258269.

Carroll, J., McCarthy, S., and Newman, C. (2005). An econometric analysis of charitable donations in the republic of Ireland. The Economic and Social Review, 36(3),229-249.

Cragg, J. (1971). Some statistical models for limited dependent variables with application to the demand for durable goods. Econometrical, 39(5), 829-844.

CSA(Central Statistics Agency). (2018). Key Findings of the 2017/2018(2010 E.C). Agricultural Sample Surveys. Country Summary. The Federal Democratic Republic of Ethiopia, Central Statistical Agency, Addis Ababa.

Daniel Asfaw, and Mulugeta Neka. (2017). Factors affecting adoption of soil and water conservation practices: The case of Wereillu Woreda (district), South Wollo zone, Amhara region, Ethiopia. International Soil and Water Conservation Research, (5), 273-279. 
Daniel Mengistu, Woldeamlak Bewket, and Rattan Lal. (2015). Conservation Effects on Soil Quality and Climate Change Adaptability of Ethiopian Watersheds. Land Degradation and Development, 27, 16031621.

Eyerusalem Girma. (2017). Farmers' Adoption Decision and Intensity of use in Soil and Water Conservation Structures in Tigray. For Partial Fulfilment of the Requirement for the Master of Science Degree in Economics, Mekelle University.

FAO (Food and Agriculture Organization) (2006). The world reference base for soil resources. A framework for international classification, correlation, and communication. Rome, Italy.

Fekadu Mengistu, and Engdawork Assefa. (2019). Farmers' decision to adopt watershed management practices in Gibe basin, southwest Ethiopia. International Soil and Water Conservation Research 7, 376387.

Fisseha Negash, and Tewodros Mulualem. (2014). The enhanced land-use system through cassava/maize intercropping in the south region of Ethiopia. Sky Journal of Agricultural Research 3(10), $196-200$.

Fontes, F. P. (2020). "Soil and Water Conservation technology adoption and labor allocation: Evidence from Ethiopia," World Development, Elsevier,127(C).

Gebeyehu Taye, Jean Poesen, Bas, Van Wesemael, Matthias Vanmaercke, Danieal Teka, Jozef Deckers, Willem Maetens, Jan Nyssen, Vincent Hallet, and Nigussie Haregeweyn. (2013). Effects of land use, slope gradient, and soil and water conservation structures on runoff and soil loss in semi-arid Northern Ethiopia. Physical Geography 34, 236-259.

Gebreselassie, S., Kirui, O., and Mirzabaev, A. (2015). Economics of land degradation and improvement in Ethiopia. A Global Assessment for Sustainable Development, 401-430.

Gizachew, Shewaye Yifru, and Birhan Asmame Miheretu. (2021). Farmers' Adoption of Soil and Water Conservation Practices: the Case of Lege-lafto Watershed, Dessie Zuria District, South Wollo, Ethiopia. Department of Geography and Environmental Studies, Wollo University, Dessie, Ethiopia.

Greene, W. (2000). Econometric analysis, 4th edition. New York University.

Gujarati, ND. (2003). Basic econometrics (4th edition). New York: McGraw Hill.

Hassen Beshir. (2013). Factors Affecting the Adoption and Intensity of Use of Improved Forages in North East Highlands of Ethiopia. Journal of Experimental Agriculture International, 4(1), 12-27.

Kalkidan Fikirie. (2021). Determinants of Adoption of Soil and Water Conservation Technologies in Coffee-Growing Areas of Ethiopia. International Journal of Food Science and Agriculture, 5(1), $189-198$. 
Kebede Wolka, Mulder Jan, and Birhanu Biazin. (2018). "Effects of soil and water conservation techniques on crop yield, runoff and soil loss in Sub-Saharan Africa: A review," Agricultural Water Management, Elsevier, 207(C), 67-79.

Melkie Erkie. (2016). Assessment of Farmers' Awareness and Adoption on Soil and Water Conservation Practices: the Case of Borebor Micro Watershed, Dera Woreda, Ethiopia. A Thesis Submitted to the School of Graduate Studies of Addis Ababa University in Partial Fulfillment of the Requirement for The Degree of Master in Biology, Addis Ababa University.

Million Sileshi, Reubener Kadigi, R.M., Mutabazi, K.D., and Sieber, S. (2019). Determinants for the adoption of physical soil and water conservation measures by smallholder farmers in Ethiopia. International Soil and Water Conservation Research, 7, 354-361.

MoARD (Ministry of Agriculture and Rural Development). (2010). Ethiopian Strategic Investment Framework for Sustainable Land Management. The Federal Democratic Republic of Ethiopia, Addis Ababa.

Mohammed Gedefaw, and Teshome Soromessa. (2015). Land degradation and its impact in the highlands of Ethiopia: A case study in Kutaber wereda, South wollo, Ethiopia. Global Journal of Agriculture and Agricultural Sciences 3(8), 288-294.

Mulat Guadie, Eyayu Molla, Mulatie Mekonnen, and Artemi Cerda. (2020). Effects of Soil Bund and StoneFaced Soil Bund on Soil Physicochemical Properties and Crop Yield Under Rain-Fed Conditions of Northwest Ethiopia. Land, 9(1), 13.

Mulatie Mekonnen, S.D, Kesstra, J.E, Baartman, C.J, Ritsema, and A.M, Melesse. (2015). Evaluating sediment storage dams: structural off-site sediment trapping measures in northwest Ethiopia CIG 41,722.

Muluken G. Wordofa, Eric N. Okoyo, and Eliso Erkalo. (2020). Factors influencing adoption of improved structural soil and water conservation measures in Eastern Ethiopia. Environmental Systems Research 9, $1-11$.

Nigatu Dabi, Kalkidan Fikirie, and Tewodros Mulualem. (2017). Soil and Water Conservation Practices on Crop Productivity and its Economic Implications in Ethiopia: A Review. Asian Journal of Agricultural Research, 11(4), 128-136.

Nigussie Haregeweyn, Atsushi Tsunekawa, Jan Nyssen, Jean Poesen, Mitsuru Tsubo, Derege Tsegaye Meshesha, Brigitta Schütt, Enyew Adgo, and Firew Tegegne. (2015). Soil erosion and conservation in Ethiopia: A review. Progress in Physical Geography 39(6), 750-74.

Olawuyi, Seyi Olalekan, and Mushunje, Abbyssinia. (2019). Determinants of adoption and use-intensity of soil and water conservation practices among smallholder farmers in Nigeria. African Journal of Food 
Agriculture Nutrition and Development 19(03), 14571-14586.

Sarah Kagoya, Krishna P. Paudel, and Nadhomi L Daniel. (2018). Awareness and Adoption of Soil and Water Conservation Technologies in a Developing Country: A Case of Nabajuzi Watershed in Central Uganda. Environmental Management, 61,188-196.

Tamrat Sinore, Endalikachew Kissi, and Abebayehu Aticho. (2018). The effects of biological soil conservation practices and community perception toward these practices in the Lemo District of Southern Ethiopia. International Soil and Water Conservation Research 6(2), 79-202.

Teklu Erkossa; A., Wodneh; B., Desalegn; G., and Taye. (2015). Linking soil erosion to on-site financial cost: lessons from watersheds in the Blue Nile basin. Solid Earth, 6, 765-774.

Temitope O. Ojo, Lloyd J.S. Baiyegunhi, Adetoso A. Adetoro, and Abiodun A. Ogundeji. (2021). Adoption of soil and water conservation technology and its effect on the productivity of smallholder rice farmers in Southwest Nigeria. Heliyon 7(3), 2405-8440 e06433.

Tesfaye Samuel Saguye. (2017). Analysis of farmers' perception on the impact of land degradation hazard on agricultural land productivity in Jeldu district in West Shewa Zone, Oromia, Ethiopia. Journal of Agricultural Extension and Rural Development,9(6), 111-123.

Tsega Adego, Belay Simane, and Getachew Abebe Woldie. (2018). Sustainability, institutional arrangement, and challenges of community-based climate-smart practices in northwest Ethiopia. Agriculture and Food Security, 7(56).

Zemenu Degie Abebe, and Minale Amare Sewnet. (2014). Adoption of soil conservation practices in north Achefer district, northwest Ethiopia. Chinese Journal of Population Resources and Environment,12(3), 261-268.

Zenebe Adimassu, K., Mekonnen, C., Yirga, and A., Kessler. (2014). Effect of soil bunds on runoff, soil and nutrient losses, and crop yield. Land Degradation and Development 25(6), 554 -564.

Zenebe Adimassu, Simon Langan, and Jennie Barron. (2018). Highlights of Soil and Water Conservation Investments in Four Regions of Ethiopia. Colombo, Sri Lanka: International Water Management Institute (IWMI). (IWMI Working Paper 182), 35.

Zenebe Adimasu, Aad Kessler, and Huib, Hengsdijk. (2012). Exploring determinants of farmers' investments in land management in the Central Rift Valley of Ethiopia. Applied Geography, 35(1-2), 191198.

Zewditu, Y. (2019). Factors Affecting the Adoption of Soil and Water Conservation Practices: The Case of Dokema Wenze and Gshieni Watersheds, Northwest, Ethiopia. A Thesis Submitted to the Departments of Natural Resource Management, School of Graduate Studies in Partial Fulfillment of the Requirements for 
the Degree of Master of Science (M.Sc.), In Watershed Management and Soil and Water Conservation Bahir dar University, Bahir Dar.

\section{Tables}

Tables 2 and 8-9 are not available with this version

\section{Appendix}

The Appendix is not available with this version

\section{Figures}

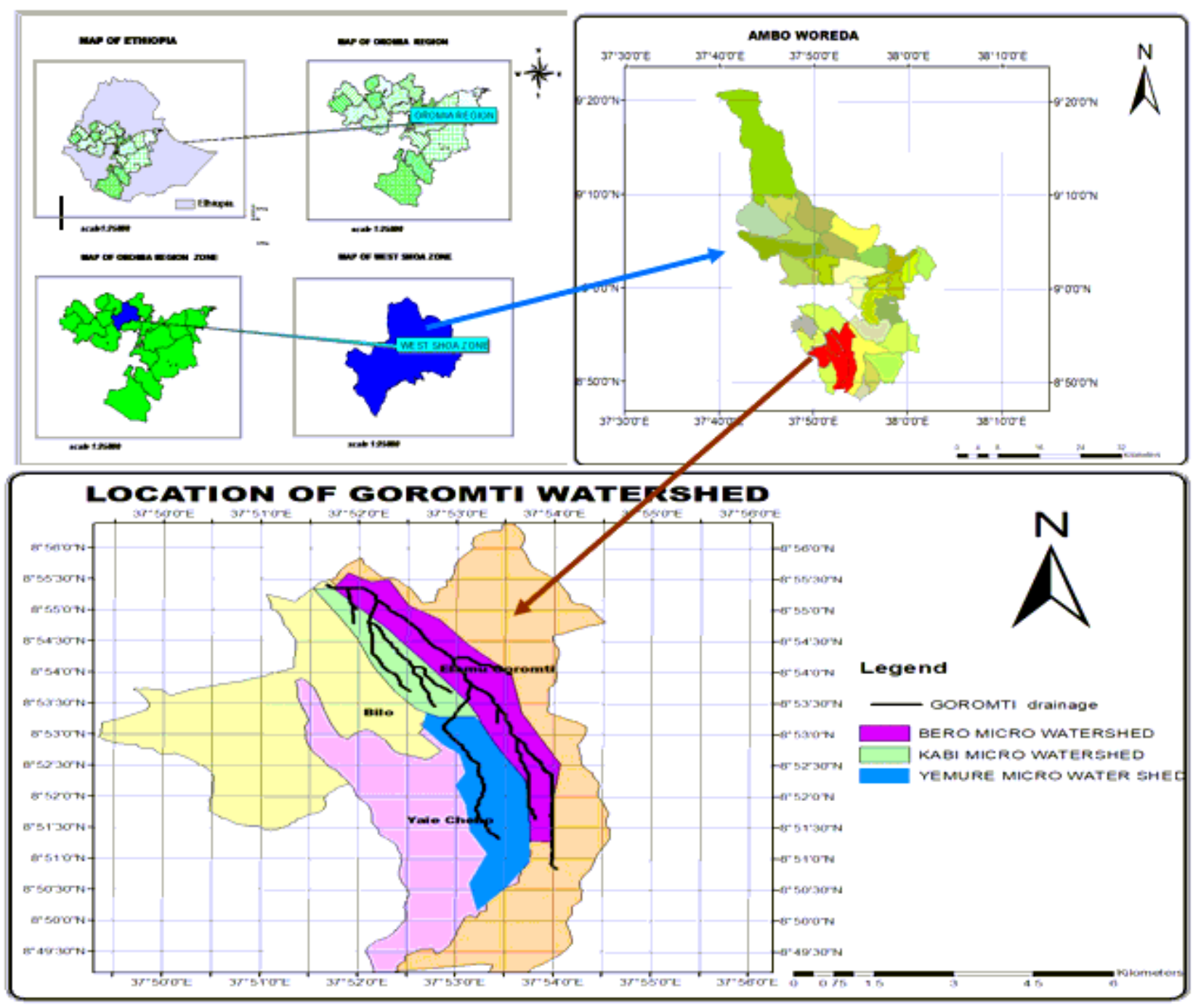

Figure 1

Map of the study area 


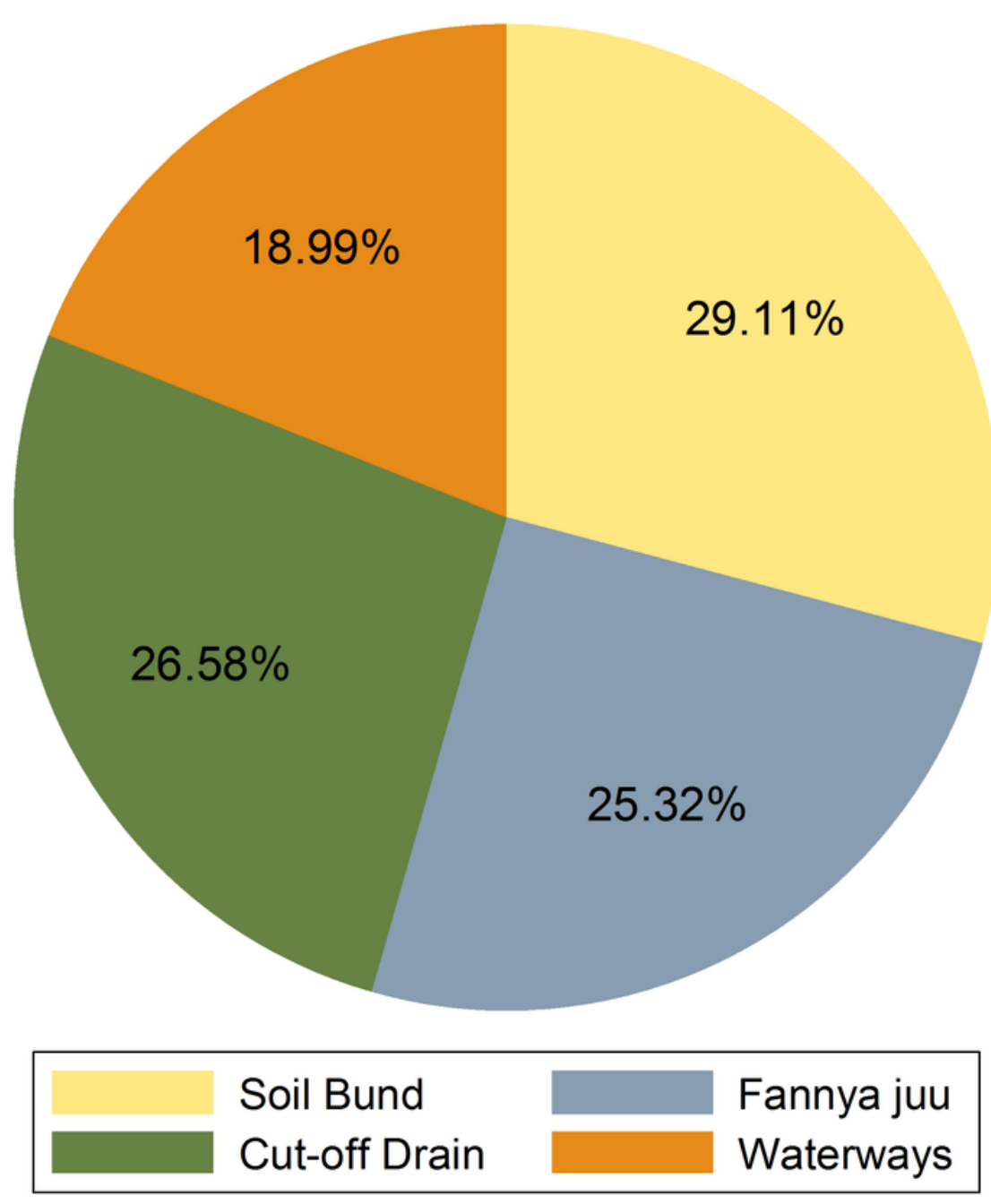

Figure 2

Types of physical SWC practices adopted in the study area

Source: Own surveyed data of 2021 


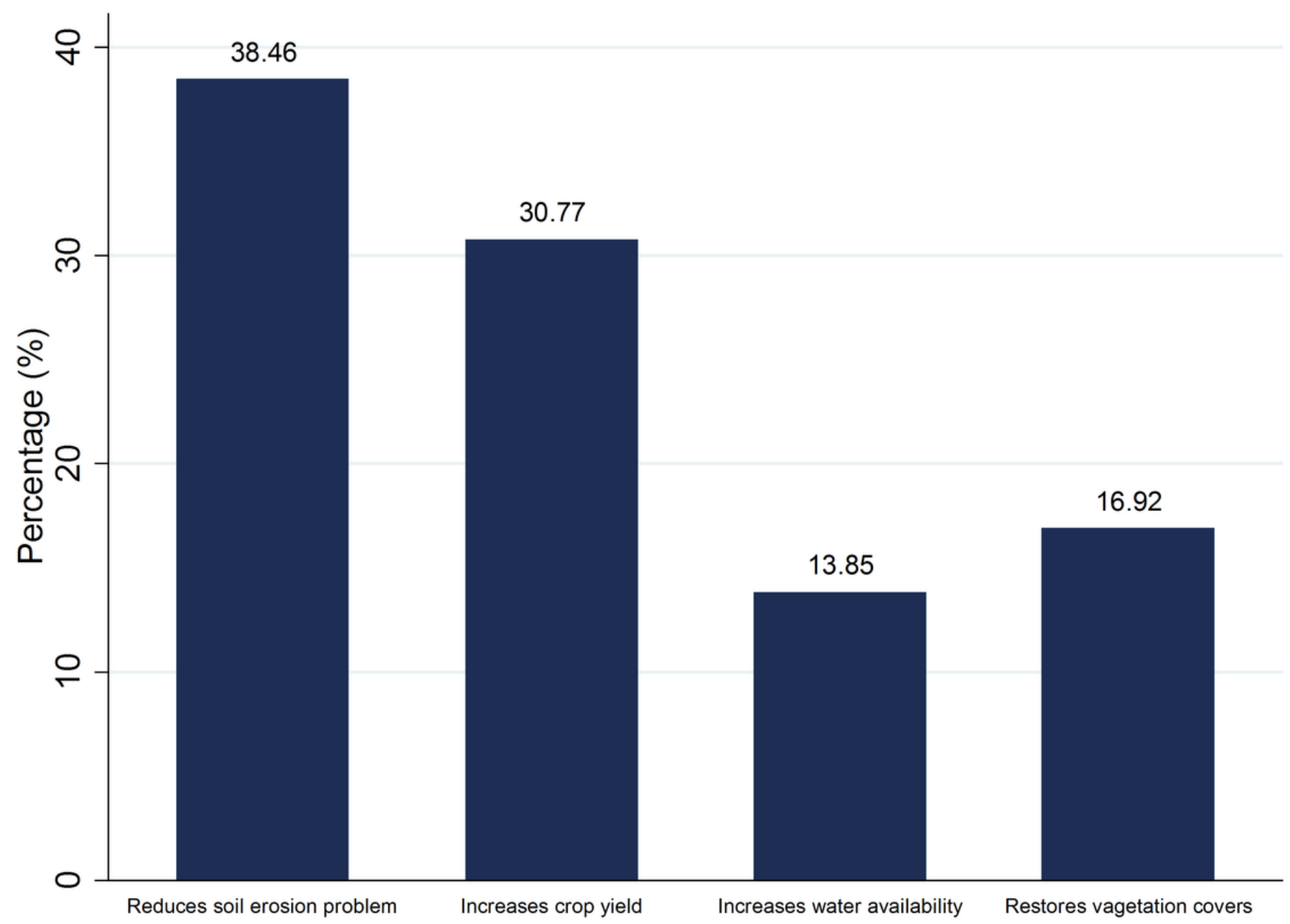

\section{Figure 3}

The advantages obtained from adopting physical SWC practices

Source: Own surveyed result 2021 